\title{
Testicular Cancer pNX TNM Finding v8
}

National Cancer Institute

\section{Source}

National Cancer Institute. Testicular Cancer pNX TNM Finding v8. NCI Thesaurus. Code C140220.

Testicular cancer in which the regional lymph nodes cannot be assessed. (from AJCC 8th Ed.) 